\section{A conclusão do artigo de A. Roazzi}

Publicamos aqui a conclusão do artigo, $O$ desenvolvimento individual, o contexto social e a prática de pesquisa, de Antonio Roazzi (University of Oxford, Department of Experimental Psychology). que não constou na edição anterior:

Discutimos aqui como os fatores de desenvolvimento intra-individual estão estreitamente dependentes do meio imediato e, conseqüentemente, como uma visăo do mundo está construída sobre os esquemas de categorizaçăo que as pessoas usam na vida diária. Em outras palavras, as estruturas essenciais do desenvolvimento humano estăo mútua $e$ casualmente interligadas com alteraçōes ambientais. $O$ ambiente deveria ser visto como um complexo intrincado de variáveis em níveis diferenciados, conectadas umas com as outras e dependentes, seja nos efeitos das açõ dos indivíduos sobre o contexto, seja no impacto destas variáveis em outros níveis contextuais.

A implicação desta visão é que a compreensão da conduta humana deve estar baseada nảo só na compreensão do contexto social, mas também em uma variedade de outros fatores, tais como papeis (Psathas, 1968), objetivos (Gauvain e Rogoff, 1986; Zinchenko, 1981), o uso por parte dos indivíduos do significado simbólico na interpretação do comportamento (Kagan, 1967) e a sua compreensão da tarefa. Estes fatores sảo em parte socialmente determinados.

O estudo das habilidades cognitivas nảo pode ser confinado a processos psicológicos auto-suficientes em índivíduos. Isto porque o indivíduo nāo pode ser visto como tendo uma auto-identidade, abstraída do seu contexto social. Os indivíduos estão relacionados às mais amplas influências da cultura, instituiçōes educacionais $e$ os diferentes grupos sociais, com os quais o indivíduo se identifica e com as quais ele interage. Ou seja, instituiçōes, tradiçōes históricas e cultura determinam - contexto de desenvolvimento cognitivo, - que não acontece, como afirmado por Perret-Clermont, Brun, Saada e Schubauer-Leoni (1984), em um vazio cultural onde cada aspecto necessita ser redescoberto pessoalmente por cada individuo.
Este ponto de vista implicaria considerar o indivíduo como fonte de todas suas elaboraçôes, inclusive as cognitivas; e em segundo lugar as determinantes do comportamento como derivadas principalmente dos componentes biológicos.

Conseqüentemente, segundo o postulado deste trabalho, experimento e contexto social são dois elementos que estão estreitamente relacionados, já que $\epsilon$ impossível pensar em executar experimentos em vacuum social. De acordo com Tajfel (1972) esta premissa implica: "(i) que não pode ser assumido que alguém já tenha conseguido criar tal vacuum;(ii) que uma analise do contexto social do experimento e da situação social que isto representa deve sempre ser considerada; (iii) que experimentos especialmente planejados devem ser conduzidos com proposito explícito de testarhipótesessobre as características do contexto social que determina $e$ interage com os modos de operaçào dos processos cognitivos" (p. 84).

Uma falta de atenção para o contexto social em uma situação experimental, por exemplo, não permite ao examinador determinar quais significados as situaçōes possuem para os sujeitos. Todos estes fatores, contexto social, significado simbólico, papel objetivo estão de alguma maneira interligados com uma experiência cultural específica, de maneira que não é simples separar as atividades de um indivíduo do contexto intrincado em que estes ocorrem. Onde diferenças entre grupos culturais aparecem, estas devem considerar o número diferenciado de experiências práticas da vida diária de cada um. Assim, em comparaçōes transculturaise sociais, todo o conjunto de açōes e circunstâncias sociais pertencentes à experiência diária normal deve ser considerado, constituindo-se como referencial para o estudo da conduta dos indivíduos. Tais aspectos, devido às suas implicaçōes científicas, devem ser considerados sobretudo nas pesquisas psicológicas passíveis de serem facilmente influenciados por variáveis externas ao planejamento experimental.

\section{Um projeto piloto na Cadeia Pública de Santos}

Estimulada pela leitura do Depoimento de Clarisse Duro Goldberg, Prestdio: uma nova possibilidade de atuagäo, edicăo $n^{\circ}$ 2/87, a psicóloga Rosa Maria $V a l$ Benes enviou-nos um relato sobre seu proprio trabalho. O objetivo da Revista ao publicar este tipo de carta é o de divulgat quem trabalba com o quê, no País. Extraimos alguns trechos do relato da colega:

"(...) Atuo em conjunto com o assistente social José Luiz Benes, na Cadeia Pública de Santos, Estado de São Paulo, há quase um ano e meio. Na realidade, estamos desenvolvendo um projeto piloto nesta cadeia, coligado à Vara de Execucóes Criminais do Fórum de Santos, sendo que, pelo seu resultado satisfatório, será estendido as demais cadeias da Baixada Santista.

Este projeto vem servir de "abertura" para a continuidade de idéias que temos em mente: a implantação de equipes multiprofissionais atuantes dentro do regime carcerário, estendendo-se à saída do regime fechado no que se refere as Casas dos Presos Albergados que, no nosso ponto de vista, são fundamentais para a reintegracão do detento à sociedade, desde que tenha uma infra-estrutura apropriada pa. ra atingir os objetivos propostos.

Atualmente estou desenvolvendo um trabalho apenas de atendimento individual aos reeducandos, sendo os mesmos selecionados - dada a importância e problemática de cada caso - pelo Assistente Social, pela Direçāo da Cadeia, pelo Juiz de Direito da Vara de Execuções Criminais, pelos advogados, pelos presos portariados, e até mesmo pedidos diretos através de bilhetes e/ou de contatos pessoais nas galerias ou lugares correlatos.

Tenho atendido reeducandos que es. tão para submeter-se a exames psicológi. cos ou psiquiátricos, ou ainda que foran reprovados na área de Psiquiatria Foren. se, com o intento de conseguir seus benefi. cios albergues. Atendo também reeducan. dos que se encontram em estado de dete. rioraçāo mental (por exemplo, psicose carcerária $\mathrm{em}$ plena progressẫo), ou ainda problemas emocionais manifestos. $E$ reeducandos com as chamadas "medidas de tratamento" impostas por lei, para acompanhamento psicologico.

Atualmente, estão sendo enviados a mim, pelo Juiz, os reeducandos para serem examinados $e$, a seguir, dar o "parecer" sobre sua compatibilidade psicológica para atingir o benefício de prisão albergue, o que antes era realizado somente pelo setor de Psiquiatria Forense."

Para contatos com Rosa M. Val Benes, o telefone é (0132) 66-1927. 